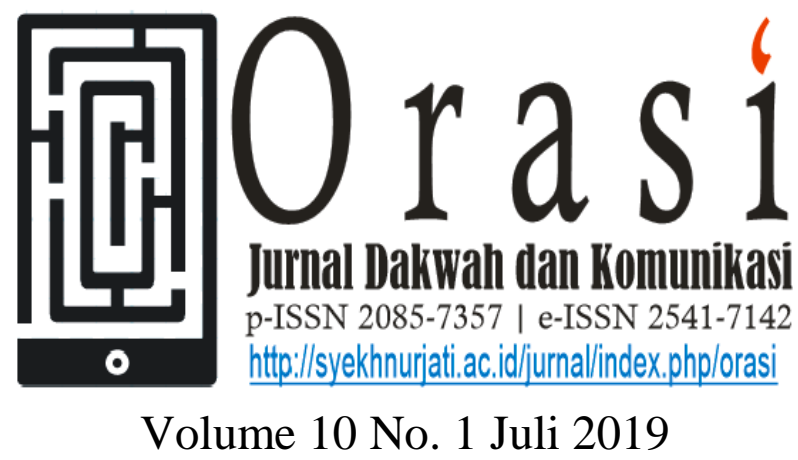

\title{
TEKNOLOGI INFORMASI SEBAGAI MEDIA KOMUNIKASI PESAN DAKWAH
}

\author{
Asriyanti Rosmalina
}

\author{
Komunikasi dan Penyiaran Islam, IAIN Syekh Nurjati Cirebon \\ Jl. Perjuangan By Pass Sunyaragi Cirebon \\ e-mail: rossmalina@yahoo.com
}

\begin{abstract}
Information technology has an impact on the emergence of challenges for Islamic missionary activists in Indonesia to change their conventional patterns of da'wah to information technology-based da'wah or combine conventional da'wah with information technology-based da'wah. As a result, various Islamic organizations were not left behind to create official sites or even social media as a means of conveying da'wah, in response to the challenge.
\end{abstract}

Keywords: Information Technology, Communication, Da'wah

\section{ABSTRAK}

Teknologi informasi berimbas pada munculnya tantangan bagi aktivis dakwah Islam di Indonesia untuk merubah pola dakwahnya yang bersifat konvensional kepada dakwah yang berbasis teknologi informasi atau mengkombinasikan antara dakwah konvensional dengan dakwah berbasis teknologi informasi. Alhasil, pelbagai ormas Islam pun tidak ketinggalan untuk menciptakan situs-situs resmi atau bahkan media-media sosial sebagai sarana menyampaikandakwah, demi menjawab tantangan tersebut.

Kata Kunci : Teknologi Informasi, Komunikasi, Dakwah

\section{Pendahuluan}

Nabi Muhammad SAW pernah menegaskan kepada umatnya suatu ketika, Sampaikanlah daripadaku walau satu ayat.". Ujaran yang sangat terkenal tersebut bernilai ajakan kepada para penganut agama Islam untuk senantiasa menyempatkan diri berdakwah dan berbagi ilmu pengetahuan bagi sesama, kapanpun dan di manapun, serta dengan media apapun. Sejak masa Rasullulah hingga masa kekhalifahan Umar bin Khatab, dakwah Islam lebih banyak dilakukan secara lisan. Baru pada tahun 644 M ketika Islam dipimpin oleh Utsman bin 
Affan, dakwah mulai dilakukan secara tertulis. Pada saat itu Al-Qur'an sebagai kita suci umat Islam mulai dibukukan, digandakan dan disebarluaskan ke wilayah Islam di penjuru dunia.

Semangat dakwah "walau hanya satu ayat" menjadi spirit yang melandasi kerja dakwah dalam rangka mengakkan agama Allah. Metode dan media dakwah Islam terus berevolusi hingga saat ini. Sejak masa dakwah yang lebih mengedepankan retorika dan penyampaian pesan Tuhan secara lisan, penulisan wahyu dalam lembaranlembaran tertulis (seperti; lempengan batu, kulit pohoru daun atau kulit hewan), hingga penggunaan kertas sebagai sarana menulis. Kini media dakwah telah menggunakan medium bit, binary dan digital. Dakwah dengan media internet inilah yang sekarang menjadi salah satu tren yang mampu membantu penyebar-luasan ajaran Islam secara lebih mudah dan masif.

Lahirnya teknologi informasi selain sebagai tantangan besar bagi aktivis dakwak di satu sisi, juga merupakan peluang yang sangat besar untuk melakukan aktivitas dakwah di sisi yang lain. Teknologi informasi telah menciptakan ruang baru yang tidak memiliki batas, baik secara geografis, perbedaan tingkat ekonomi, tingkat pendidikan. agama, politik, maupun sosialbudaya. Hal ini membuat ruang gerak dakwah yang awalnya terbatas pada komunitas dan ditentukan oleh letak geografis menjadi lebih luas, terbuka, dan lebih efisien dalam waktu, tenaga, ataupun biaya. Bila pada zaman dahulu aktivitas dakwah menghabiskan banyak waktu dan biaya untuk menuju suatu tempat dan memerlukan face to face dengan mad'u-nya, kini dakwah bisa dilakukan hanya dengan duduk di depan komputer yang memiliki koneksi internet. Melalui teknologi informasi tersebut, semua orang dapat mengakses bermacam inforaiasi dari berbagai sumber diseluruh dunia. Alhasil dengan media internet dakwah menjadi lebih mudah dan murah, serta dapat diakses oleh semua kalangan.

Menurut A.W. Widjaya dalam bukunya, Komunikasi (Komunikasi dan Hubungan Masyarakat), pesan seharusnya mempunyai inti pesan (tema) sebagai pengarah dalam upaya mencoba mengubah sikap dan tingkah laku komunikan. Pesan ini dapat bersifat informatif, persuasif, dan koersif. (Widjaja, 2002:15) Pesan bersifat informatif, dalam artian memberikan keterangan-keterangan dan kemudian komunikan dapat mengambil kesimpulan sendiri. Dalam situasi tertentu pesan informatif lebih berhasil daripada pesan persuasif, misalnya pada kalangan cendikiawan.

Pesan juga bersifat persuasif atau membujuk, yakni membangkitkan pengertian dan kesadaran seseorang bahwa apa yang kita sampaikan akan memberikan rupa pendapat atau sikap sehingga ada perubahan. Tetapi perubahan yang terjadi itu adalah atas kehendak sendiri, misalnya pada waktu diadakan lobby, atau pada waktu istirahat makan bersama.

Selain itu, pesan itu bisa bersifat koersif, yakni sifat pesan yang memaksa dengan menggunakan sanksi-sanksi. Bentuk yang terkenal dari penyampaian pesan secara ini adalah agitasi dengan penekananpenekanan yang menimbulkan tekanan batin dan ketakutan diantara sesamanya dan pada kalangan publik. Koersif dapat berbentuk perintah, instruksi dan sebagainya.

Untuk merumuskan pesan agar mengena, pesan yang disampaikan hams tepat, ibarat kita membidik dan menembak, maka peluru yang keluar haruslah tepat kena sasarannya. Agar mengena, maka pesan harus direncanakan (dipersiapkan) secara baik, serta sesuai dengan kebutuhan kita. Kemudian pesan juga harus menggunakan bahasa yang tepat dimengerti kedua belah pihak. Dan terakhir, pesanitu harus menarik 
minat dan kebutuhan pribadi penerima serta menimbulkan kepuasan. (Widjaja, 2002:15)

Pendapat lain mengatakan syaratsyarat pesan hams memenuhi: 1) umum, berisikan hal-hal yang umum dan mudah dipahami oleh komunikan/'audience, bukan soal-soal yang cuma berarti atau hanya dipahami oleh seseorang atau kelompok tertentu; 2) jelas dan gamblang, pesan yang disampaikan tidak samar-samar. Jika mengambilperumparaaan hendaklah diusahakan contoh yang senyata mungkin,agar tidak ditafsirkan menyimpang dari yang kita kehendaki; 3) bahasa yang jelas, sejauh mungkin hindarkanlah menggunakan istilah-istilah yang tidak dipahami oleh si penerima atau pendengar. Gunakanlah bahasa yang jelas dan sederhana yang cocok dengan komunikan, daerah dankondisi dimana kita berkomunikasi, hatihati pula dengan istilah ataukata-kata dari bahasa daerah yang dapat ditafsirkan lain oleh komunikan; 4) positif, secara kodrati manusia selalu tidak ingin mendengar dan melihat hal-hal yang tidak menyenangkan dirinya. Oleh karena itu setiap pesan agar diusahakan dalam bentuk positif; 5) seimbang, pesan yang disampaikan oleh karena kita membutuhkan selalu yangbaikbaik saja atau jelek-jelek saja. Hal ini kadang-kadang berakibatsenjata makan tuan, cenderung ditolak atau tidak diterima oleh komunikan; 6) penyesuaian dengan keinginan komunikan, orang-orang yang menjadi sasaran dari komunikasi yang kita sampaikan selalu mempunyai keinginankeinginan tertentu, oleh sebab itu pesanpesan yang disampaikan haras dapat disesuaikan dengan keinginan-keinginan komunikan tersebut (Widjaja, 2002:15-16)

\section{Pembahasan}

Secara harfiyah, dakwah berasal dari kata da'ayad'u da'watan yang artinyal panggilan, seruan atau ajakan. Maksudnya adalah mengajak dan menyeru umat manusia agar mengakui Allah Swt sebagai Tuhan yang benar, lalu menajalankan kehidupan sesuai dengan ketentuanketentuan-Nya yang tertuang dalam AlQuran dan Sunnah.(Ahmad Yani, 2005:1)

Dakwah secara definitif dirumuskan dalam teks dan konteks yang sangat variatif oleh para ahli. Diantaranya definisi dakwah yang menekankan proses pemberian motivasi untuk melakukan pesan dakwah (ajaran Islam) yang digagas oleh Syeikh Ali Mahfudz. Beliau mendefinisikan dakwah adalah "mendorong manusia pada kebaikan dan petunjuk, memerintahkanperbuatan yang diketahui kebenarannya, melarang perbuatan yangmerusak individu dan orang banyakagar mereka memperolehkebahagiaan di dunia dan akhirat" (Ali Mahfudz dalam Asep Muhidin, 2002:32)

Sementara itu, definisi dakwah lainnya yang menekankan kepada proses penyebaran pesan dakwah dengan mempertimbangkan penggunaan metode, media dan pesan yang sesuai dengan situasi dan kondisi mad'u digagas oleh Ahmad Ghalwusy (dalam Asep Muhidin, 2002:33) yaitu "menyampaikan pesan Islam kepada manusia di setiap waktu dan tempat dengan berbagai metode dan media yang sesuai dengan kondisi dan situasi para penerima pesan dakwah."

Unsur-unsur dakwah adalah komponen-komponen yang terdapat dalam setiap kegiatan dakwah, diantaranya:

a. $\quad D a ' i$ (Pengirim Pesan Dakwah)

Da'i adalah orang yang melaksanakan dakwah baik secara lisan, tulisan maupun perbuatan yang dilakukan baik secara individu, kelompok atau melalui lembaga/organisasi.

b. Mad'u (Penerima Pesan Dakwah)

Mad'u yaitu manusia yang menjadi sasaran dakwah atau penerima dakwah, baik secara individu ataupun kelompok. Baik 
manusia yang beragama Islam atau tidak, dengan kata lain manusia secara keseluruhan. Kepada manusia yang belum beragama Islam, dakwah bertujuan untuk mengajak mereka mengikuti agama Islam. Sedangkan kepada orang-orang yang telah beragama Islam, dakwah bertujuan untuk meningkatkan iman, Islam dan ihsan.

\section{c. Maddah (Materi Dakwah)}

Maddah adalah isi pesan atau materi yang disampaikan da'i kepada mad'u. Dalam hal ini sudah jelas bahwa yang menjadi materi dakwah adalah ajaran Islam itu sendiri yang bersumber dari al-Quran dan Sunnah.

\section{d. Was Hah (Media Dakwah)}

Wasilah adalah media atau alat yang digunakan untuk menyampaikan materi dakwah kepada mad'u. Untuk menyampaikan ajaran Islam kepada umat, dakwah dapat menggunakan berbagai media. Hamzah Ya'qub membagiwasilah dakwah ini menjadi lima macam, yaitu; lisan, tulisan, lukisan/gambar, audiovisual dan akhlak.

\section{e. Thariqah (Metode Dakwah)}

Metode dakwah adalah jalan atau cara yang dipakai juru dakwah untuk menyampaikan ajaran materi dakwah Islam. Dalam menyampaikan suatu pesan dakwah, metode memiliki peranan yang sangat penting. Karena suatu pesan yang isinya baik tetapi disampaikan dengan cara yang tidak benar atau kurang tepat dapat menjadi halangan sampainya pesan tersebut kepada mad'u.

\section{f. Atsar (Efek Dakwah)}

Dalam setiap akivitas dakwah pasti akan menimbulkan reaksi. Artinya, jika dakwah telah dilakukan oleh seorang da'i dengan materi dakwah, wasilah dan thariqah tertentu, maka akan timbul respon atau efek dari mad'u. Atsar ini sangat besar artinya dalam menentukan langkah-langkah dakwah berikutnya. (Munir dan Wahyu Ilahi, 2006: 21-34)
Pendekatan kegiatan dakwah dapat dilakukan dengan pendekatan dakwah ucapan (bi al-qawl), dakwah melalui perbuatan (bi al- 'amat) dan melalui tulisan (bi al-kitabah). Dari penjabaran bentuk kegiatan itu lahir empat ragarn kegiatan dakwah, diantaranya:

1) Tabligh Islam, sebagai upaya penerangan dan penyebaran pesan Islam

2) Irsyad Islam, sebagai upaya penyuluhan dan bimbingan Islam

3) Tadbir Islam, sebagai upaya pemberdayaan umat dalam menjalankan ajaran Islam melalui lembaga-lembaga dakwah

4) Tathwir Islam, sebagai upaya pemberdayaan ekonomi keumatan (Asep

Muhidin, 2002:35)

Kegiatan tabligh dan ta'lim dilakukan dalam rangka pencerdasan dan pencerahan masyarakat melalui kegiatan pokok: sosialisasi, internalisasi, dan eksternalisasi nilai ajaran islam, dengan menggunakan sarana mimbar dan media massa.

Sementara itu, pendekatan Irsyad dilakukan dalam rangka pemecahan masalah psikologis melalui kegiatan pokok; bimbingan penyuluhan pribadi, danbimbingan penyuluhan keluarga baik secara preventif maupun kuratif. Tabligh dan irsyad ini menyangkut kondisioning pemahaman, persepsi dan sikap.

Upaya tadbir dilakukan dalam rangka rekayasa sosial dan pemberdayaan masyarakat menuju kehidupan yang lebih baik, peningkatan kualitas sumber daya manusia serta pranata sosial keagamaan, menumbuhkanserta mengembangkan perekonomian dan kesejahteraan masyarakat dengan kegiatan pokok; penyusunankebijakan, perencanaan program,pembagian tugasdan pengorganisasian, pelaksanaan 
danmonitoring, serta evaluasi pembangunan masyarakat dari aspek perekonomian dan kesejahteraannya.Tadbir menyangkutdakwah melalui pembangunan.

Sedangkan upaya tathwir dilakukan dalam rangka peningkatan sosial budaya masyarakat yang dilakukan dengan kegiatan pokok; transformasi dan pelembagaan nilainilain ajaran Islam dalam realitas kehidupan umat yang menyangkut kemanusiaan, seni, budaya, dan kehidupan bermasyarakat, penggalangan ukhuwah islamiyah dan pemeliharaan lingkungan. Dengan kata lain, tathwir ini berkaitan dengan kegiatan dakwah melalui pendekatan sosial budaya. (Asep Muhidin, 2002:37-38).

Bila pesan merupakan setiap pemberitahuan, kata, atau komunikasi baik lisan maupun tertulis, yang dikirimkan dari satu orang ke orang lain, maka pesan dakwah bisa dirumuskan sebagai seruan, ujaran, atau ajakan dalam bentuk lisan maupun tulisan yang berisi nilai-nilai Al-Quran dan al-AlHadits, serta bertujuan membawa penerima pesan menuju ketaatan kepada Allah Swt.

Senada dengan rumusan di atas, praktisi dakwah Toto Tasmara mengartikan pesan dakwah sebagai semua pemyataan yang bersumber dari Al Quran dan Sunnah baik tertulis maupun lisan dengan pesan-pesan (risalah) tentang hablun min Allah atau mиa 'amalah ma 'a Al-Khaliq dan hablun min alnas atau mиa 'malah ma 'a al-khalqi, yakni mengupayakan adanya keseimbangan hubungan (tawazun) antara keduanya. (Tasmara, 2002:43)

Model komunikasi Islam yang pesannya bersumber pada Al-Quran dan AlHadits Nabi, tentulah pesan itu bersifat imperatif atau wajib hukumnya untuk dilaksanakan, karena merupakan pesan kebenaran berdasarkan firman Allah Swt dan Al-Hadits Nabi. Pesan tidak boleh merupakan sensasi, berita dusta, kefasikan, pelintiran kata-kata dan kebohongan publik (public lies). Meskipun demikian, penyampaian pesan-pesan dakwah harus tetap mengedepankan etika \{akhlaq alkarimah) dan upaya yang bersifat persuasif.Berkaitan dengan pesan-pesan yang bersumber pada AIQuran dan Hadis, dalam dakwah, pesan-pesan itu masuk dalam unsur materi dakwah. Materi dakwah adalah semua ajaran yang datangnya dari Allah SWT yang dibawa oleh Rosulullah SAW untuk disampaikan kepada seluruh umat manusia yang berada di muka bumi. (Masy'ari, 1979:19)

Materi dakwah sebagai pesan dakwah merupakan isi ajakan, anjuran dan idea gerakan dalam rangka mencapai tujuan dakwah. Sebagai isi ajakan dan idea gerakan dimaksudkan agar manusia mau menerima dan memahami serta mengikuti ajaran tersebut, sehingga ajaran Islam ini benarbenar diketahui, difaharni, dihayati dan selanjutnya diamalkan sebagai pedoman hidup dan kehidupannya.

Pada dasarnya materi dakwah Islam tergantung pada tujuan dakwah yang ingin dicapai. Namun secara global dapatlah dikatakan bahwa materi dakwah dapat diklasifikasikan menjadi tiga hal pokok, yaitu : masalah akidah, masalah syari'ah dan masalah budi pekerti (akhlak al-karimah):

a. Bidang Akidah

Akidah Islam sabagai sistem kepercayaan yang berpokok pangkal atas kepercayaan dan keyakinan yang sungguhsungguh akan ke-Esaan Allah Swt adalah merupakan materi terpenting dalam kegiatan dakwah. Sebagaimana diketahui bahwa rukun iman itu ada 6 (enam) dimana rukun yang pertama adalah iman kepada Allah swt. Yang merupakan pokok dari rukun iman yang lain; sedangkan rukun iman secara keseluruhan menjadi asas dari ajaran islam secara keseluruhan pula. Dalam hubungan ini Al-Maududi mengatakan:

"Dalam ajaran Muhammad Saw, percaya kepada Allah itu sangat penting dan 
prinsipil. Itulah yang menjadi pusat urat nadi Islam dan sumber kekuatan. Semua kepercayaan, perintah dan undang-undang Islam berdiri diatas dasar ini, dan semua mempunyai kekuatan dari sumber ini". (Syukir, 1983: 62)

Dalam hubungannya dengan iman ini, al-Nawawi mengatakan bahwa iman itu adalah keyakinan ucapan dan perbuatan yang bisa bertambah dan berkurang. Oleh karena itu, penanaman dan pembinaan keimanan bagi penerima dakwah secara terus menerus perlu dilakukan, baik yang masih lemah imannya maupun yang sudah kuat imannya. Selain penanaman dan pendidikan akidah, maka penolakan dan bantahan terhadap faham lain diluar Islam perlu dilakukan, seperti terhadap faham meterialisme, atheisme dan ajaran lain yang tidak sesuai dengan akidah Islam. Lain daripada itu pesan dakwah dalam bidang akidah ini juga berisi panduan menjaga akidah Islam dari segala bentuk penyimpangan.

Materi dakwah yang berkaitan dengan akidah ini meliputi aspek, antara lain kepercayaan kepada Allah, kepercayaan kepada Rasul Allah, kepercayaan kepadakitab-kitab Allah, kepercayaan kepada hari akhir, kepercayaan kepada yang ghaib termasuk percaya kepada Malaikat, Surga, Neraka dan Iain-lain. (Aminuddin, $\mathrm{tt}: 75)$

b. Bidang Syariah

Syariah dalam Islam adalah berhubungan erat dengan amal lahir (nyata) dalam rangka mentaati semиa peraturan atau hukitm Allah guna mengatur hubungan antara manusia dengan Tuhannya, dan mengatur pergaulan hidup antara sesama manusia. Hal ini dijelaskan dalam sabda Rosulullah saw. yang artinya :

"Islam adalah bahwasanya engkau menyembah Allah SWT. Dan janganlah engkau mempersekutukan-Nya dengan sesiiatu pun, mengerjakan sembahyang, membayar zakat yang wajib, berpuasa dalam bulan Ramadhan dan menunaikan ibadah haji ke Baitullah". (H.R. BukhariMuslim)

Hadis di atas mecerminkan hubungan antara manusia dengan Allah Swt. Artinya perbuatan yang tennasuk dalam ranah syariah bukan saja terbatas pada ibadah kepada Allah, akan tetapi juga termasuk masalah-masalah yang berkenaan dengan pergauian hidup antara sesama manusia, seperti hukum jual beli, berumah tangga, warisan kepemimpinan dan amal saleh lainnya. Demikian juga laranganlarangan dari Allah seperti minum, berzina, mencuri dan sebagainya termasuk pula masalah-masalah yang menjadi materi dakwah Islam. (Syukir, 1983:62)

\section{c. Budi Pekerti atau Akhlaq al-Karimah}

Masalah akhiak dalam pelaksanaan dakwah (sebagai materi dakwah) merupakan pelengkap saja, yakni untuk melengkapi keimanan dan keislaman seseorang. Meskipun ahlak ini berfungsi sebagai pelengkap, bukan berarti masalah ahlak kurang penting dibanding dengan masalah keimanan dan keislaman. Sebab Rasulullah sendiri pernah bersabda:

Sesungguhnya aku diutus (dengan tujuan) menyempurnakan akhiak. ${ }^{2}$

Keseluruhan materi dakwah yang tersebut diatas pada dasarnya bersumber dari dua sumber, yaitu :

\section{1) Al-Quran dan Al-Hadits}

Agama Islam adalah agama yang menganut ajaran kitab Allah yakni Al-Quran dan al-Hadits Rasulullah saw. Yang mana kedua sumber ini merupakan sumber utama ajaran-ajaran Islam.

2) Ra 'yu Ulama (Opini Ulama)

Islam menganjurkan umatnya untuk berpikir, berijtihad menemukan hukumhukum yang sangat operasional sebagai tafsiran dan takwil Al-Quran dan al-Hadits. Maka dari itu pemikiran dan penelitian para ulama ini dapat pula dijadikan sebagi sumber kedua setelah Al-Quran dan al-Hadits. 
Dengan kata lain penemuan baru yang tidak bertentangan dengan Al-Quran dan al-Hadits dapat pula dijadikan sebagai sumber materi yJL dakwah. (Syukir, 1983:63-64).

Di Indonesia Situs-situs Islam mulai bermunculan sekitar awal tahun seperti www,myquran.com, www.alislam.or.id,

www,laskarjihad.or.id,www.kisdi.or.id,www, pesantrenvirtual.com,www.iiman.co.id,www. hidavatullah.com, www.republika.co.id dan banyak lagi lainnya yang turut menyemarakkan Internet dengan berbagai format sajian. (www.id.wikipedia.org, 13 Mei 2014, 09:35)

Prinsip kerja dari internet ialah graphycal system dimana gambar-gambar yang muncul dalam layar monitor merupakan "terjemahan dari" vektor-vektor dan garis sehingga menimbulkan gerakan-gerakan animasi yang hampir nyata. Meski masih bergerak dalam monitor komputer, tapi tahukah bahwa para pakar internet sekarang tengah berupaya menghasilkan sebuah produk yang ingin memunculkan figur dengan cara lain, tidak dalam kotak monitor seperti sekarang ini. Gambaran mengenai hal ini, misalnya dapat kita lihat dalam -salah satunya- Minority Report yang dibintangi oleh Tom Cruise. Perlu diketahui bahwa teknologi telah tersedia meski masih dalam batas yang minimum. (Fachrurozi, dalam Aep, 2004: 116)

Sebagai produk teknologi, internet dapat dikatakan tidak bebas nilai karena pada dasamya teknologi dibuat untuk membantu memecahkan masalah dan untuk memenuhi kebutuhan manusia dalam menjalankan aktivitas sehari-hari. Tetapi, dari sisi pemakai, baik buruknya suatu produk teknologi itu tergantung bagaimana kita melihat dan menggunakannya. Pada akhirnya nilai positif atau negatif suatu produk teknologi tergantung dari niat dan motivasi penggunanya yang akan menentukan apakah itu bermanfaat atau sebaliknya.
Di sini, perlu pendekatan yang sesuai untuk menjelaskan kepada masyarakat mengenai suatu produk teknologi yang dalam hal ini adalah internet. Utamanya terhadap komunitas-komunitas muslim tradisional yang menjadi center of influence selama berabad-abad. Mengingat, peran komunitas tradisional dan tokoh khansmatik sangat signifikan bagi masayarakat Indonesia sejak zaman para Wali sampai saat ini. Terlepas dari itu semua, para penggerak dakwah diharap mampu bersaing dalam memanfaatkan internet sebagai salah satu media dakwah.

\section{Simpulan}

Manusia di zaman yang serba canggih ini dituntut untuk mampu sesuaikan diri dengan segala kemajuan di berbagai bidang, tak terkecuali di bsdang komunikasi dan informasi. Bidang ini membutuhkan media untuk digunakan sebagai sarana pengantar informasi kepada khalayak. Media tersebut bermacam-macam, ada yang bersifat cetak dan elektronik. Media cetak misalnya koran, majalah, tabloid, buku, selebaran dan sebagainya. Sementara media elektronik dapat berupa televisi, radio, telepon, kaset dan Iain-lain.

Selain media - media yang tersebut diatas dunia telekomunikasi akhir-akhir ini sedang digemparkan dengan hadirnya teknologi informasi keberadaanya disambut luar biasa karean memberikan banyak kemudahan bagi penggunanya. Teknologi komunikasi digunakan sebagai nedia komunikasi pesan dakwah.

\section{Daftar Pustaka}

Masy'ari, A. (1979). Studi Tentang Ilmu Dakwah. Banjarmasin: Citra

Muhiddin, Asep. (2002). Dakwah Prespektif Al -Quran. Bandung : Pustaka Setia Munir dan Wahyu Ilahi. (2006). Manajemen Dakwah. Jakarta: Prenada Media 
Syukir, Asmuni. (1989). Dasar-dasar Strategi

Dakwah Islam. Surabaya : Al-Ikhlas

Tasmara, Toto. (1997). Komunikasi Dakwah.

Jakarta : Gaya Media Pratama

Widjaja, A.W. (2002). Komunikasi dan hubungan masyarakat, Jakarta : PT. Bumi Aksara.

Yani, Ahmad. (2005). Bekal menjadi khatib dan mubaligh, Jakarta : Al-Qalam 